Mateusz Antoniuk

Uniwersytet Jagielloński

mateusz.antoniuk@uj.edu.pl

\title{
Herbert, Narcyz i mucha albo proces tekstotwórczy jako praca reinterpretacji ${ }^{1}$
}

\author{
Herbert, Narcissus and the Fly, or the Text-creating Process as a Work of \\ Reinterpretation
}

\begin{abstract}
The article presents the history of Zbigniew Herbert's work on the prose miniature devoted to mythological Narcissus. The analysis of the preserved manuscript versions serves to illustrate the multi-layer process of reinterpretation of the myth. Herbert in the "laboratory of the draft" tested various concepts of this reinterpretation. The Herbert's texts on Narcissus published in print reveal only to a limited degree the scale of the author's invention in deconstructing and transforming the canonical versions of the Greek myth.
\end{abstract}

Keywords: Zbigniew Herbert, genetic criticism, archive

Streszczenie: Artykuł przedstawia historię pracy Zbigniewa Herberta nad prozatorską miniaturą poświęconą postaci mitologicznego Narcyza. Analiza zachowanych wersji rękopiśmiennych służy unaocznieniu wielowariantowości procesu reinterpretacji mitu. Herbert w „laboratorium brulionu” testował rozmaite koncepty reinterpretacyjne. Herbertowskie teksty o Narcyzie ogłoszone drukiem tylko w niewielkim stopniu ujawniają skalę autorskiej inwencji w dekonstruowaniu i przekształcaniu kanonicznych wersji greckiego mitu.

Słowa kluczowe: Zbigniew Herbert, krytyka genetyczna, archiwum

${ }^{1}$ Artykuł powstał w ramach realizacji grantu Narodowego Programu Rozwoju Humanistyki „Archiwum Zbigniewa Herberta - studia nad dokumentacją procesu twórczego”; nr rejestracyjny 11H 130167 82; miejsce realizacji: Wydział Polonistyki UJ; kierownik: dr Mateusz Antoniuk. 


\section{Punkt wyjścia: „wbrew legendzie”}

W roku 1999 na łamach „Zeszytów Literackich” ukazał się krótki utwór prozatorski Zbigniewa Herberta, poety i pisarza zmarłego kilkanaście miesięcy wcześniej. Tekst ów nosił tytuł Narcyz, nigdy wcześniej nie był drukowany, a zaczynał się dwoma słowami: „wbrew legendzie”.

Te dwa inicjalne wyrazy ujawniają reinterpretacyjny modus operandi utworu, istotnie będącego jeszcze jednym, kolejnym wznowieniem gry z tradycją mitologiczną, tak charakterystycznej dla autora Struny światta ${ }^{2}$. Jednocześnie to programowe „wbrew legendzie” miało charakter, bez wątpienia świadomej, symplifikacji czy myślowego skrótu: Herbert wiedział przecież doskonale, że nigdy nie istniała jedna „legenda” Narcyza, jedna narracja o jego życiu i śmierci (oraz ich upamiętnieniu). Oprócz przekazu skodyfikowanego w Owidiuszowych Metamorfozach (piękny młodzieniec gardzi miłością Echo i doprowadza swą nieczułością do jej śmierci, za karę dotknięty zostaje płomienną miłością do własnego odbicia w wodzie, kona z męki nieodwzajemnionego uczucia, a na miejscu jego śmierci wyrasta kwiat zwany narcyzem) pojawiały się przecież rozmaite wersje przekształcone, odmienne. Wedle jednej z nich nadobny Narcyz, owszem, odrzuca miłość, nie kobiety jednak, a mężczyzny, niejakiego Amejniasa, który, niczym Echo, umiera; dalej zdarzenia toczą się już w zgodzie z relacją Owidiuszową. Jeszcze ciekawsza jest wersja inna: Narcyz nie odrzuca ludzkiej miłości, przeciwnie, kocha - i nie siebie wcale, lecz siostrę bliźniaczkę. Po jej śmierci popada w rozpacz. Wpatruje się w odbicie własnego oblicza nie dlatego, że zakochał się w swym wizerunku, lecz dlatego, że tylko w ten sposób widzieć może pośrednio - tę, którą stracił z oczu (i w ogóle: stracił). Przedstawienie nie jest jednak pełnym uobecnieniem, reprezentacja nie zastępuje obecności i nie może przynieść ukojenia, dlatego też Narcyz umiera z tęsknoty33.

Mit zatem, przy bliższym poznaniu, okazuje się mniej jednorodny, niż głosi potoczne mniemanie (a trzeba dodać, że w tej krótkiej rekapitulacji i tak nie oddałem pełnej palety fabularnych odmian). Bohater opowieści okazuje się konstruktem labilnym: widzi tylko siebie, gdyż nikogo innego nie chce widzieć, to znów wpatruje się tylko w siebie, gdyż jedynie tak może ujrzeć kogoś innego. Hasło „wbrew legendzie”, otwierające Herbertowskiego Narcyza, mogłoby właściwie brzmieć: „wbrew legendom”. Jakoż reinterpretacja opowieści przyjęta przez polskiego poetę zaprzecza każdemu ze znanych mitografom przekazów, żadnemu nie okazując posłuszeństwa. Narcyz nie jest tu ideałem piękna. „Wbrew legendzie, która przypisuje mu wielką urodę, Narcyz był pospolitym

2 Zob. M. Adamiec, „...Pomnik trochę niezupetny...”. Rzecz o apokryfach i poezji Zbigniewa Herberta, Gdańsk 1996.

3 Zob. P. Grimal, Stownik mitologii greckiej i rzymskiej, tłum. M. Bronarska i in., wyd. 2, Wrocław 1990, s. 245. 
chłopakiem o wulgarnych rysach, nieczystej cerze, szerokich barach i długich kończynach" ${ }^{4}$ Nie jest też nieczuły, nie gardzi miłością Echo.

Jednakże brutalność i głupota potrzebują spoiwa, trzeciego pierwiastka, by stworzyć trwałą molekułę charakteru. Tym pierwiastkiem jest najczęściej sentymentalizm.

Więc $i$ on zakochał się.

Wybranka nosiła imię Echo5.

Związek Narcyza i Echo dochodzi do skutku. I choć po pewnym czasie ulega rozpadowi, bieg wydarzeń nie prowadzi do pojętej dosłownie śmierci któregokolwiek z kochanków.

Nastąpiło zerwanie. Narcyz nie wrócił do swych dawnych zajęć. Zaczął rozmyślać.

Echo natomiast wstąiła do klasztoru natury. Innych klasztorów podówczas nie znano. Kiedy jary, parowy, leśne ostępy i polany nawiedzają grupy dziwnych ludzi, objuczonych pieczonymi kurami, butersznytami i jajami na twardo - niewidzialna Echo towarzyszy tym eksploratorom, powtarzając dwa ostatnie słowa ich donośnych pohukiwań. Można powiedzieć, że z rozpaczy stała się stewardesą przyrody.

A Narcyz, jako się rzekło, dumał ${ }^{6}$.

Jestem czytelnikiem obdarzonym pasją krytyczno-genetycznej penetracji, toteż spoglądając na domknięty, spójny utwór, mający swój początek, środek i koniec, zastanawiam się często: jakie procesy pisarskie, jakie działania twórcze złożyły się na tę postać tekstu, którą widzę na zadrukowanej stronicy książki, na gazetowej szpalcie? Interesuje mnie poniekąd stare formalistyczne pytanie: ,jak jest zrobiony" utwór (niech będzie to Ptaszcz Mikołaja Gogola, Don Kichot Miguela de Cervantesa, Narcyz Herberta)? Odpowiedzi chcę jednak udzielać niewyłącznie (i nie przede wszystkim) w kategoriach synchronicznej analizy strukturalnej (rozkładającej statyczną jedność tekstu na elementy, określającej ich funkcjonalne zależności, niewnikającej jednak w sam proces ich wytwarzania), lecz w kategoriach diachronicznej analizy krytycznogenetycznej (stawiającej sobie za cel przychwycenie, w takim stopniu, w jakim to możliwe, procesu wytwarzania tekstowej konstrukcji). Z takiego właśnie zaciekawienia wyrasta niniejszy szkic.

\section{Narcyz w archiwum - podstawowe informacje}

Utwór pt. Narcyz w swym pierwodruku na łamach „Zeszytów Literackich” zajmuje kilka stron. Tymczasem genetyczne dossier pracy nad tematem Narcyza (czyli zbiór wszystkich zachowanych dokumentów, będących materialnym

\footnotetext{
${ }^{4}$ Z. Herbert, Narcyz, „Zeszyty Literackie” 1999, nr 4, s. 8.

5 Tamże.

${ }^{6}$ Tamże, s. 9.
} 
śladem działań tekstotwórczych), zdeponowane w całości w Archiwum Zbigniewa Herberta (Biblioteka Narodowa w Warszawie), obejmuje około 40 kart. Są to zarówno kartki Herbertowych notatników ${ }^{7}$ jak i - częściej - kartki luźne ${ }^{8}$.

W jakim okresie ów zbiór dokumentów przyrastał? W jakim czasie Herbert pracował nad Narcyzem? Nie sposób udzielić odpowiedzi dokładnej i pewnej, gdyż - poza jednym wyjątkiem - zapiski pozbawione są bezpośredniej, autorskiej datacji. Analizując wszelkie dostępne przesłanki, sformułować można jednak ostrożną hipotezę. Otóż zamysł pracy nad utworem reinterpretującym mit Narcyza mógł się zrodzić już pod koniec lat siedemdziesiątych $\mathrm{XX}$ wieku'. Prace tekstotwórcze trwały - zapewne ze zmiennym nasileniem $\mathrm{w}$ latach osiemdziesiątych, niewykluczone, że także w pierwszej połowie lat dziewięćdziesiątych ${ }^{10}$. Na pewno zajmował się Herbert Narcyzem w lipcu 1996 roku, na dwa lata przed śmiercią, z tego bowiem okresu pochodzi jedyny bezpośrednio datowany rękopis utworu ${ }^{11} . \mathrm{Z}$ tak przybliżonej chronologii wynika wniosek jeden: autor Hermesa, psa i gwiazdy pracował (z przerwami, nierówną intensywnością etc.) nad prozatorskim utworem o Narcyzie w ciągu lat około piętnastu. Długo - jak na prozatorską miniaturę.

Pod względem funkcjonalnym w obrębie dossier zaproponować można następującą systematykę:

a) Notatki o charakterze planistycznym, czyli uwagi charakteryzujące postaci opowieści, plany rozwiązań fabularnych - ujęte nie w formę zwartego tekstu, lecz haseł do rozwinięcia.

b) Bruliony - większe lub mniejsze całości tekstowe, zapisane odręcznie.

c) Maszynopisy i komputeropisy (jeden z komputeropisów stał się podstawą pierwodruku na łamach „Zeszytów Literackich”).

Najmniejlicznesądokumenty typu, „c, więcejjestdokumentów typu,„a”,zdecydowanie najliczniejsze są dokumenty typu „b”, stanowią one ok. 90\% wszy-

7 Zob. Archiwum Zbigniewa Herberta w Bibliotece Narodowej w Warszawie (wszystkie dokumenty przywoływane w tym artykule pochodzą z tej lokalizacji; dalej: AZH), akc. 17955 , t. $105,112,120,122,136,155$.

${ }^{8}$ Kartki luźne ulokowane są w teczkach dokumentujących pracę nad Królem mrówek, dużym projektem prozatorskim, którego częścią miał być utwór o Narcyzie; zob. AZH, akc. 17856 , t. 2, 3, cz. $2,5$.

9 Sam tytuł Narcyz - usytuowany na pustej stronie, nieznajdujący partnera w choćby jednym wyrazie powstającego tekstu - pojawia się w Notatniku nr 105, szacunkowo datowanym na rok 1978.

10 W Notatniku nr 112 - datowanym wedle publikacji Archiwum Zbigniewa Herberta. Inwentarz (oprac. H. Citko, Warszawa 2008) na rok 1982 i zawierającym notatkę z artykułu prasowego, opublikowanego 13 lutego 1983 roku - pojawia się już obszerniejszy urywek tekstowy, niewątpliwie należący do Narcyza. Ślady brulionowej pracy nad utworem zawarte są także w Notatnikach nr 120 (na którego okładce widnieją daty 1987 i, chyba, 1991), 122 (na okładce: rok 1988) i 136 (bez dat, szacowany przez Archiwum Zbigniewa Herberta. Inwentarz na lata 1986-1989).

${ }^{11}$ W Notatniku nr 155 znajduje się zapis, zawierający redakcję utworu pt. Narcyz, datowaną przez Herberta na 17.07.1996 (alternatywie widnieje tam również data 4.07.1996). 
stkich materiałów zachowanych. Narcyz nie był szczegółowo planowany (zapewne dlatego, że od początku autor nie wyobrażał go sobie inaczej niż jako utworu krótkiego, o nieskomplikowanej fabule, nielicznych postaciach, niewymagającego więc ustaleń w zakresie kompozycji), był natomiast utworem intensywnie pisanym. Dynamika procesu twórczego w tym wypadku ukazuje serię niezależnych od siebie, w znakomitej większości przerywanych prób zbudowania tekstu, kończących się po kilkudziesięciu, kilkunastu, a czasem nawet i po kilku - zdaniach.

$\mathrm{Z}$ jakiej przyczyny utwór o Narcyzie tak intensywnie, rzekłbym, multiplikuje się w papierach Herberta? Dlaczego autor podejmuje próbę napisania małej prozy wiele razy, wciąż przerywając i wciąż zaczynając od nowa, każdorazowo inaczej, nierzadko „zupełnie inaczej”? Co sprawia, że wraca do niej w ciągu lat, wypełnionych przecież pracą nad innymi tekstami prozatorskimi oraz poetyckimi? I skąd ta nieproporcjonalność rozmiarów brulionowego pola i rozmiarów skończonego utworu? Najkrótsza odpowiedź, jakiej mógłbym udzielić - znając wszystkie zachowane ślady pracy - brzmi: tym, czego Herbert szuka, jest nie tyle idealne brzmienie tekstu, optymalny efekt stylistyczno-retoryczny, lecz - koncept reinterpretacyjny. Autor za każdym razem usiłuje wywrócić i odwrócić sens oraz schemat mitologicznej opowieści, wciąż jednak nie jest usatysfakcjonowany osiąganym rezultatem. U źródeł pisania Narcyza tkwi, tak dla Herberta typowe, zamiłowanie do reinterpretacji i subwersji kanonicznych opowieści kulturowych; ale mechanizm odpowiedzialny za przedłużanie i komplikowanie akcji pisania utworu Narcyz jest reinterpretacją reintepretacji, subwersją subwersji. Bruliony okazują się w tej sytuacji śladem procesu nie tylko, nie przede wszystkim nawet, tekstotwórczego, lecz mitoprzetwórczego.

Czytając (należałoby nawet powiedzieć: odcyfrowując) rozmaite manuskryptowe redakcje, urywki i próbki utworu o Narcyzie natrafiamy raz po raz na passusy „meta-reinterpretacyjne”, to jest dotyczące samej zasady podejrzliwego myślenia o micie. Niemal wszystkie krążą wokół jednego głównego motywu, jednej myśli przewodniej. Jest to myśl o semantycznej nieprzejrzystości mitu Narcyza ${ }^{12}$. Jak na przykład w takim oto urywku ${ }^{13}$ :

${ }^{12}$ Bodaj tylko raz zapisuje Herbert uwagę stwierdzającą coś dokładnie przeciwnego: „W opowieści o narcyzie znajduje się znacząca przestroga [powyżej nadpisane: łatwo odnaleźć znaczącą przestrogę]" (AZH, akc. 17 856, t. 2, s. 56). Ale ta konstatacja hermeneutycznej otwartości mitu, mówiąc obrazowo, zawisa w próżni niezapisanej kartki. Inskrypcja się urywa, zapowiedź nie zostaje spełniona: nie dowiemy się już, jaką „przestrogę" można bez trudu wydobyć z mitycznej opowieści i jakie jest jej znaczenie.

${ }^{13} \mathrm{~W}$ cytatach z brulionowych zapisków Herberta przyjęto w niniejszym artykule następujące oznaczenia: (...) - wyraz nieczytelny, czcionka przekreślona - skreślenia w rękopisie, [?] oznaczenie lekcji wątpliwej (odnosi się do wyrazu poprzedzającego znak). 
*** Opowieść o Narcyzie jest narracyjnie wątła, a jej morał - niejasny.

$$
\text { jego osoby przejrzystych }
$$

Wszystko co dotyczy utkane jest z pierzchliwych cieni

$$
\text { - myślisz - }
$$

Szarm, uroda, wdzięk piękno wreszcie - cóż to wszystko znaczy, zaledwie słowa bezważkie które rzucone w wodę nie zostawiają kręgów na powierzchni, ale czy jest tak naprawdę czy to nie my sami, my mordercy tajemnic nie chcemy dojrzeć poza tkaniną złudy pulsującej bólem - ciężkiej Istoty Rzeczy, istoty w której pulsuje ciemny ból

(AZH, akc. 17 856, t. 2, s. 48)

Lub w tym akapicie z innej próby tekstowej:

\section{NARCYZ}

Jeśli jest coś interesującego w historii Narcyza to pewna (trudno powiedzieć czy zamierzona) niezdarność niezborność tego przekazu jakby wymyślona była przez przestraszone dziecko spocone i niemiłosiernie jąkające się, dziecko które stoi przed nami zdyszane o pałających purpurowych z emocji policzkach i usiłuje wyrzucić z siebie że napotkało w lesie w czasie rannej wyprawy po jagody niewielki kurhan kopczyk przerośnięty zielskiem a w nim kamienie jakby fragmenty pogruchotanej płaskorzeźby leżące pod ciężką warstwą ziemi zarosłej gęstą i gwałtowną trawą, bez ładu i składu, dziwne i leżące tu bardzo długo, tajemnicze ułomki czegoś wielkiego i mały (...) lasu stara się nas zainteresować i pobudzić do działania zaklinając się co chwila że mówi świętą prawdę.

(AZH, akc. 17 856, t. 2, s. 64)

I jeszcze jeden przykład, jeszcze jedna uwaga, rzucona przez pisarza reinterpretatora:

Mit o Narcyzie - niejasny, kruchy, niepokojący, zaliczali uczeni do

\section{zarys}

mitów wegetacyjnych, chcieli zagłuszyć wołanie przepaści, przyszłej kolebkę okrutnego losu

tragedii, (...) (...) (nawet) źródło losu.

Przekazy mityczne przedstawiane są tu konsekwentnie jako opowieść niepokojąca, gdyż nadto oczywista. Kulturowa narracja to przesłona, pozór, atrapa sensu, przez którą należy się przebić, by podjąć próbę wyłuskania tego, co rzeczywiste, realne, co nie prześwituje nawet poprzez szpary i niezborności mitograficznego dyskursu. Ale - jest. 
Mówiąc obrazowo: pisanie i przepisywanie Narcyza (utworu) oraz multiplikowanie Narcyza (bohatera zyskującego w brulionach niejako zwielokrotnioną osobowość) jest ciągłą próbą przebicia się ku temu „czemus", ku tej „realności”. Lub, jak kto woli, to próba odegrania retorycznego spektaklu, próba zainscenizowania czy sfingowania hermeneutycznego procesu, mającego, rzekomo, odkrywać istotę mitu. Rzecz w tym, że Herbert, mimo podejmowania kolejnych prób, wciąż nie może zyskać pewności, że zdołał się przebić do ukrytego znaczenia, albo wciąż nie ma przekonania, że zdołał dostatecznie sugestywnie „upozorować” proces hermeneutyczny. Dlatego zaczernia kolejne kartki, podejmuje nowe próby.

Właśnie ten wysiłek twórczy - a ściślej, jego brulionowy ślad - jest przedmiotem mojego szkicu.

\section{Wariacje narcystyczne}

Uważna lektura wszystkich materiałów archiwalnych pozwala wyodrębnić co najmniej trzy warianty reinterpretacji postaci Narcyza, testowane w brulionowym laboratorium Herberta, a nieznane czytelnikom Króla mrówek. Te trzy koncepcje (każda z nich pojawia się w co najmniej kilku tekstowych próbkach realizacji) można określić następującymi hasłami: Narcyz - filozof spragniony samopoznania, Narcyz - tragicznie zbuntowany przeciw własnemu przeznaczeniu, Narcyz - filozof autodestrukcji. Co hasła te znaczą i na jakie tekstowe praxis się przekładają, spróbuję teraz powiedzieć.

a) Filozof spragniony samopoznania

Spójrzmy na następującą transliterację:

(Narcyz II

Najbardziej stosownym do celu miejscem są odludzia

Jak wiadomo najstosowniejszym miejscem do tego celu są odludzia. Nasz bohater tedy

zaszył się w gęstwinę leśną. Całe dotychczasowe jego życie wydało mu się bez sensu. Tliła w nim niejasna chęć poznania siebie

Najbardziej stosownym miejscem do tego celu są jak wiadomo odludzia. Nasz bohater zaszył się tedy w leśną głuszę. Całe dotychczasowe jego życie wydało mu się bez sensu. I zapłonęła w nim, zatliła

$$
\text { żądza }
$$

niejasna ale mocna chęć poznania. (...)

Przez długie wieki zanim zjawią się filozofowie ze swoim zbawczym [?] bagażem abstrakcji dręczą[?] te same wielkie problemy Boga, świata, podmiotu, przedmiotu, tyle że przybierają one formę obrazów, (...) mitów, majaków sennych. Trzeba oddać Narcyzowi sprawiedliwość: na długo przed Sokratesem zmierzył się on naiwnie ale z zapałem z sokratejskim nakazem poznaj samego siebie 
A zatem, Narcyz - presokratykiem. Czy raczej, to właściwsze określenie, Sokratesem avant la lettre, antycypacją wielkiego Ateńczyka, bohatera Jaskini filozofów (dramatu, zresztą, poświęconego w dużej mierze problemowi introspekcji, samopoznania). Jaki był jednak rezultat rozważań Narcyza, do jakich przeświadczeń na temat samego siebie - podmiotu myślącego doszedł ów pierwszy filozof podmiotowości? Zapis oddany w powyższej transliteracji, jak widzimy, urywa się dość gwałtownie, mniej więcej w połowie strony. Poniżej, tam, gdzie oczekiwalibyśmy dalszego ciągu opowieści, zaczyna się przestrzeń niezapisana. Jedynie przy dolnym marginesie, przy samej krawędzi kartki, w dużym oddaleniu od analizowanego już passusu, pojawia się taka oto inskrypcja:

nad tym

nagle

Zaczął zastanawiać się nad tym kim jest naprawdę. Któż mógł przypuszczać, że taka otchłań otworzy się przed tym prostaczkiem?

Zatem Narcyz miał się stać w tej projekcji bohaterem doświadczającym grozy samopoznania. Ale co było otchłanią Narcyza? Można oczywiście odpowiedzieć: on sam stał się dla siebie otchłanią, pochłonęła go jego własna podmiotowość. Prawda, lecz co w tej otchłani zobaczył Narcyz? Nie wiemy. Nie wiemy również, czy wiedział to Herbert. Niewykluczone (choć również: niemożliwe do udowodnienia), iż sam pisarz reinterpretator nie wypracował pomysłu na to, czego dowiedział się o sobie reinterpretowany bohater. Biel niezapisanego papieru jest, być może, luką w procesie reinterpretacji mitu, śladem ujawniającym fiasko wysiłków „wywrotowej” wyobraźni, która nie zdołała domknąć polemicznej kontrlektury.

Ujęcie Narcyza jako filozofa skupionego na poznawaniu samego siebie powraca w brulionach kilkukrotnie i w rozmaitych zabarwieniach. Szczególnie frapujące ze względów intertekstualnych wydają się dwie adnotacje widniejące na marginesie innej karty. Są to hasła: „egotyczna religia” oraz „o [?] swój [?] poswoje do swego" (AZH, akc. 17 856, t. 2, s. 65). Druga z tych formuł coś przecież przypomina... „Swój do swego po swoje!” to wszak formuła powtarzana w Gombrowiczowskim Kosmosie, urastająca do rangi hasła wyrażającego filozofię życiową jednego z bohaterów, mianowicie Leona Wojtysa, programowo ograniczającego kontakt ze światem zewnętrznym i czerpiącego satysfakcję z obcowania z samym sobą (własną cielesnością, pamięcią, wyobraźnią, prywatnym językiem etc. $)^{14}$. Czy możliwe, aby był to przypadek? Czy raczej - i ku takiej skłaniam się opcji - Herbertowi pracującemu nad reinterpretacją mitu rzeczywiście przypomina się powieść

14 „Swój do swego po swoje” to także nacjonalistyczne hasło używane w okresie międzywojennym, wzywające Polaków do bojkotu handlu żydowskiego i preferowania handlu polskiego. Kwestię tę pozostawiam jednak na boku, skupiając się w swojej interpretacji na ewentualnym nawiązaniu do Gombrowicza. 
Gombrowicza? A więc pisarza, którego ongiś czytał z żywą fascynacją, stopniowo, wraz z upływem czasu, stygnącą i zastępowaną przez dystans, nieufność, poczucie obcości ${ }^{15}$.

b) Narcyz - tragicznie zbuntowany przeciw własnemu przeznaczeniu

W labiryncie brulionowych, notatkowych inskrypcji napotykamy i takiego Narcyza:

W

Narcyz Późno helleński alamanach gotajski figuruje on jako syn najady i boga niewielkiej rzeczułki boga niewielkiej rzeczułki i najady

Nie ulega wątpliwości że uroda Narcyza była podstępnym albo bezmyślnym darem bogów; on

wróżbnym sam nigdy jej nie pragnął jakby przeczuwając, że stanie się dla niego złowrogim przeznaczeniem. [Brak jakichkolwiek informacji o dzieciństwie i wczesnych latach chłopięcych Narcyza, wiadomo natomiast od wczesnej młodości buntował się przeciwko.

natomiast wiemy na pewno tylko że był

[..] także wiemy napewno że dzierżawił młyn był więc młynarzem, drobnym kapitalistą co w hierarchii społecznej dawało mu pozycję ani zbyt wysoką ani wcale bynajmniej poślednią

Będąc człowiekiem środka, zarówno w poglądach politycznych jak też pod innymi względami, musiał odezuwał piękno które uosabiał jako wielką niedogodność jako narzuconą rolę, nie chciał grać nad nie chciał grać

w innych dziedzinach

Będąc człowiekiem środka zarówno w poglądach politycznych jak też pod innymi względami własną

odczuwał piękno na które został skazany jako coś niegodnego z jego naturą, jakby narzuconą rolę w sztuce której sensu nie mógł pojąć. Od wczesnej młodości buntował się przeciwko temu

15 Zob. list do Haliny Misiołkowej z dnia 1.06.1956: „Czytałem w „Kulturze” (paryskiej) Dziennik Gombrowicza. Dawno już nie przeżyłem takiego wstrząsu. To jest chyba największy pisarz polski współczesny: przenikliwy, szokujący, prowokatorski. I jak myśli, trawiąc cudze ideje" (Z. Herbert, Listy do Muzy, Gdynia 2000, s. 132). Dziesięć lat później zupełnie innego adresata Herbert będzie już przestrzegał przed twórcą Dziennika: „Bardzo mnie niepokoi Twój kontakt duchowy z Gombrowiczem (...). Strzeż się, proszę, bo to deprawator acz artysta" (Z. Herbert, C. Miłosz, Korespondencja, Warszawa 2006, s. 73, list z 11.05.1967). Stwierdzenie z listu do Miłosza jest oczywiście nacechowane żartobliwie, niemniej jednak, w zestawieniu z wcześniejszym passusem epistolarnym, wolno je chyba potraktować jako sygnał narastającego dystansu. 
i właśnie ten bunt nadaje jego postaci znamię prawdziwego tragizmu, wbrew temu eosądzili innt wyehająe tę po tym wszystkim którzy uparli się by odesłać Narcyza do botaniki w krainę niejasnych mitów wegetacyjnych.

(AZH, akc. 17 856, t. 2, s. 43)

Ten Herbertowski Narcyz nie tyle „zgłębia siebie”, co pozostaje w niezgodzie z sobą, stara się odrzucić pewien rys swojej tożsamości. Herbert dynamizuje mit; statyczną postać, cechującą się niezmiennym usposobieniem, obdarza wewnętrznym konfliktem, pęknięciem, rozdarciem nawet.

Jak wyglądać miało rozwiązanie sporu Narcyza z bogami (którzy obdarzyli go uroda), otoczeniem (które tylko na tę urodę zwracało uwagę), ale też, przede wszystkim, sporu z własnym principium individuationis? Pytanie pozostaje bez odpowiedzi, gdyż - podobnie jak w przypadku wersji o Narcyzie wpadającym w otchłań samopoznania - także i tutaj mamy tekst przerwany, zarzucony i nigdy niesfinalizowany. Można jedynie przypuszczać, że mit o Narcyzie miał być w ramach tego wyłaniającego się, lecz niewyłonionego tekstu niejako „przekodowany” - na wzór mitu o Edypie. Narcyz jest tu przecież obdarzony urodą niczym „złowrogim przeznaczeniem”; próba jej odrzucenia równałaby się więc próbie ucieczki od losu, od konieczności, od tego, co musi się stać. Ale jak dokładnie miałaby przebiegać historia Narcyza-Edypa, jakie konkretne perypetie fabularne zostałyby sprowokowane przez buntownicze działania bohatera, stającego do walki z nieuchronnym?

c) Narcyz - filozof autodestrukcji

Ostatni z wyodrębnionych tu przeze mnie Herbertowskich konceptów reinterpretacyjnych, testowanych w brulionowym laboratorium, daje się najpełniej wyczytać z takiego oto zapisu:

Nie można wykluczyć że Narcyz chyba

nieświadomie stworzył dość upowszechniony obecnie

kierunek który z braku lepszego określenia nazwijmy

degracjonalizmem lub lepiej bo zawilej degracjonalizmem integralnym.

Podstawowym twierdzeniem tej koncepcji jest intuicja że człowiek został stworzony ponad miarę swych możliwości (większość z nas to w jakimś stopniu odczuwa). A skoro tak jest, lub się być wydaje - jedynym logicznym postępowaniem jest nie wspinanie się w górę, wysiłek, doskonalenie ale świadomy upadek, degradacja schodzenie w dół $[\ldots \ldots \ldots \ldots \ldots \ldots . . . . . . .6 \mathrm{ku}$ coraz prostszym formom życia. Egzystencja pakuje swój tobołek i ucieka od esencji. O tem zdają 
się świadczyć zapiski znalezione przy Narcyzie

zapewne szkice poematu

dobrze

Jak dobrze

drzewa odchodzą do swoich domów

Jak błogo. Niebo odchodzi do nieba

A obłoki do swoich domów (nor) obłoki do obłoków drzewa do lasu.

niebo odchodzi do nieba

Ja i tylko ja niepodzielny

Ja i tylko ja

Ja samoisty niepokalany

święty

Ja samoisty, nieskalany święty

$\mathrm{Ja}$

Ja

Spokój. Coraz więcej światła

spokój. Coraz więcej światła

*/ Obłoki do swoich (...)

(AZH, akc. 17 856, t. 2, s. 66)

Stosunkowo najbliżej tu do wersji poprzednio omawianej, a więc do Narcyza zbuntowanego wobec własnej urody. Ale „ten Narcyz” jest jednak znacznie bardziej radykalny: odrzuca coś więcej niż piękno twarzy, odrzuca - samą formę człowieczego bytu. I cel swój osiąga. Dalszy ciąg zapisu brulionowego przedstawia się następująco:

-Aż wreszcie przyszło to, co przyjść musiało. W potocznym języku określenie jest krótkie jak trzask łamanej gałęzi. Opisowa definicja biologii godzi nas z tym przykrym faktem stoickim obiektywizmem mówiąc że jest to stan organizmu (a jednak stan)

wyrażający się zakończeniem procesów życiowych i prowadzący do zniszczenia osobnika jako żywego układu. Tak jest znacznie lżej.

Ci którzy odkryli zwłoki Narcyza tuż koło źródła ze zdziwieniem zauważyli że jest on dobrze zakonserwowany, suchy jak liść i prawie dwuwymiarowy.

Jest to chyba jedyny znany nauce przypadek rozwoju regresywnego polegającego jak wiadomo na uproszczeniu, zmniejszeniu pewnych organów i funkcji. U Narcyza można było stwierdzić wyraźne uwstecznienie narządów ruchu, a także zmysłów z wyjątkiem oka, zanik czynnego pobierania pożywienia. Rozwój regresywny spotykamy np. u pasożytów wewnętrznych które nadrabiają sobie ten kaprys natury progresywnym [?] rozwojem układu rozrodczego a przypadku Narcyza nie miało [?] miejsca [?]

(AZH, akc. 17 856, t. 2, s. 66)

Ten Herbertowski Narcyz nie pogrąża się w otchłani samopoznania, nie wikła się także w edypowy spór z przeznaczeniem (czyli przekleństwem własnej piękności), lecz dokonuje skutecznej autoregresji. Rzec można: skupia się na samym sobie, ale skupia w sposób paradoksalny, bo prowadzący do zatarcia, wymazania „ja”. Narcyz dokonuje autoogołocenia, samo-spustoszenia. W innych próbach tekstowych Herbert znalazł metaforę dla określenia takiego trybu 
postępowania swojego bohatera: „Narcyz jest osobliwym kanibalem a mianowicie kanibalem pożerającym samego siebie” (AZH, akc. 17 856, t. 2, s. 56).

Metafora „laboratorium”, ostatnio na gruncie polskiej humanistyki tak wyraźnie dowartościowywana ${ }^{16}$, dobrze obsługuje specyfikę Herbertowskiego procesu pisarskiego - tego akurat procesu, o którym traktuje mój artykuł. Poszczególne zapisy istotnie przypominają laboratoryjne naczynia - w każdym z nich pisarz-eksperymentator testuje różne proporcje i układy składników. Zwykle przy tym nie kończy swej „roboty”, nie dba o wytworzenie finalnego, starannie opracowanego produktu, raczej przeprowadza symulację, sprawdza, jakie właściwości osiągnie tekst przyrządzany wedle określonej procedury, a gdy już zyska w tej kwestii jasność - przerywa test, przechodzi do innej próbówki, szuka nowych rozwiązań. Wyliczmy raz jeszcze: Narcyz zgłębiający tajniki własnej, niespodziewanie skomplikowanej, „otchłannej” osobowości (wersja „a”), Narcyz odrzucający w imię bycia „człowiekiem środka” ekstrawagancję własnej piękności (wersja „b”), Narcyz dążący do samozniszczenia (wersja „c”), Narcyz pozbawiony filozoficznego temperamentu, bezrefleksyjny, wcale przy tym nie piękny (wersja drukowana w „Zeszytach Literackich”). Każdy z tych Narcyzów jest inny od Narcyza „kanonicznego”, każdy jest wobec niego „subwersywny” (każdy też odróżnia się od Narcyzów z "marginesu mitu”) - ale też wszyscy ci Herbertowscy Narcyzowie są nietożsami wzajemnie, nieekwiwalentni, niewymienni. Pisanie prozy pt. Narcyz przypomina (pokuśmy się o jeszcze jedną metaforę) budowanie gabinetu zwierciadeł, w którym rozgrywa się gra podobieństw i różnic, powtórzeń i przeinaczeń, odbić i przekształceń.

Zresztą, nie tylko Narcyz podlega brulionowym wariacjom. Postacią mniej dynamiczną, lecz także nie w pełni ustabilizowaną okazuje się jego fabularna partnerka. W utworze podanym do druku na łamach „Zeszytów Literackich” Echo jest osobą niemal autystycznie zamkniętą w sobie.

Jak określić kalectwo Echo? Mówiono o niej - niemowa, ale jest to określenie mało precyzyjne. Echo bowiem powtarzała dokładnie i bardzo wyraźnie ostatnie dwa wyrazy, kończące zdania, jakimi się do niej zwracano. Nigdy natomiast nie mówiła z własnej inicjatywy. Zgadzało się to całkowicie z jej naturą - powolną, flegmatyczną, uległą.

Podobna konstrukcja bohaterki powtarza się $\mathrm{w}$ większości próbek tekstowych (o ile w ogóle Echo zdążyła się w nich znaleźć, często bowiem próbki te urywają się tak szybko, są tak fragmentaryczne, że postać nimfy w ogóle

${ }^{16}$ Zob. R. Nycz, W stronę humanistyki innowacyjnej. Tekst jako laboratorium, „Teksty Drugie" 2013, nr 1-2. 
nie jest w nich ujęta). A jednak, uważna lektura brulionów pozwala odkryć przynajmniej jedną kontr-wersję, różną tyleż od „prawowiernego mitu”, co od większości jego Herbertowych przeinaczeń:

powzięła dziwny [?] zamiar aby rozbudzić w Nareyzie zainteresowanie intelektualne

Echo czytała mu do poduszki wczesną i dość łatwą pracę

Kanta Allgemeine Natur geschichte und

Theorie des Himmels

Nic, żadne przeżycie nawet tak bolesne jak rozstanie z Echo nie miało wpływu na idealny stan jego twarzy

uczynić

N. jakby wola zbiorowa mogła stwo[?] cud N. piękniał coraz b

stawał się coraz zawrotniej piękniejszym za sprawą oczu które go podziwiały

(AZH, akc. 17 856, t. 2, s. 40)

A więc nie Echo jako quasi-Gombrowiczowska Iwona (skoro była już mowa o Leonie z Kosmosu...), fascynująca swoim dziwnym, wsobnym, nieprzenikliwym sposobem istnienia, lecz Echo sawantka, uczona hetera podejmująca próbę rozbudzenia w Narcyzie metafizycznego temperamentu. Co wydaje się zamiarem beznadziejnym, jako że sam Narcyz jest w tej wersji utworu - powiedzmy tym razem „po witkacowsku” - „zwyczajnym bubkiem", istotą zbydlęciałą, pozbawioną zdolności przeżywania tajemnicy istnienia.

\section{Dygresja i retrospekcja: jeszcze inny Narcyz Zbigniewa Herberta}

Trzeba w tym miejscu opuścić na chwilę brulionowe próby do Króla mrówek i sięgnąc do starszych, głębszych warstw archiwum Zbigniewa Herberta. Tak się bowiem składa, że Narcyz nie pojawił się w wyobraźni Herberta dopiero w okresie pracy nad małymi mitologicznymi prozami w latach osiemdziesiątych i dziewięćdziesiątych. Figurą Narcyza Herbert posłużył się kilkadziesiąt lat wcześniej. W roku 1953 poeta pracował nad - jak się miało okazać, nigdy niesfinalizowanym - wierszem Wista ${ }^{17}$. Był to utwór alegoryczny, w którym tytułowa rzeka stawała się znakiem polskiego losu, polskiej historii. Wiersz mówił (miał mówić) o odnawialności nieszczęścia, powtarzającego się

${ }_{17}$ O historii pracy nad tym utworem piszę nieco szerzej w mojej książce Stowo raz obudzone. Poezja Czestawa Mitosza. Próby czytania, Kraków 2015, s. 177-181. 
w zbiorowej biografii każdej kolejnej polskiej generacji. Wisła nazywana była „jałowym Nilem”, „z pokolenia w pokolenie” użyźniającym ziemię pod plon nowej wojny. W takim semantycznym otoczeniu bardzo ciekawie wybrzmiewała strofa posługująca się motywem Narcyza:

$$
\begin{aligned}
& \multicolumn{1}{c}{\text { rzeką }} \\
& \text { pochylam się nad strtrgą mętną } \\
& \text { i wiem że długo twarzy [?] [...] } \\
& \text { aby odbiło się w tej wodzie } \\
& \text { jakiej nie pragnie żaden nareyz } \\
& \text { nad którą wszędzie pieśń i Narcyz } \\
& \quad \text { przeklina } \\
& \text { którą przeklina śpiew i narcyz }
\end{aligned}
$$

(AZH, akc. 17 955, t. 46, s. 7)

Frapujące są przemiany czwartego, domykającego wersu! Jak łatwo zauważyć, wers ów pojawia się tu w potrójnej postaci, w trzech redakcjach. Sens pierwszej z nich, skreślonej, można chyba pochwycić w następującej parafrazie: Wisła to rzeka, w jakiej żaden Narcyz nie chciałby się przeglądnąć, gdyż (o tym wiemy z sąsiadujących strof i wersów) jej mętne, ciemne, przygnębiające wody nie mogą być lustrem dla rozmiłowanej w sobie piękności. Podobne znaczenie zdaje się mieć również redakcja trzecia, chronologicznie najpóźniejsza: „którą przeklina śpiew i narcyz”. Pomiędzy nimi jednak odnajdujemy wersję drugą, o istotnie różnej semantyce. „Nad którą wszędzie pieśń i Narcyz”... Pojawia się tu sugestia wcale wyraźna: wiślane brzegi zamieszkują narcyzowie, polskość - ta traumatyczna, nieszczęśliwa, zraniona - ma charakter narcystyczny, polega na patologicznym rozmiłowaniu w cierpiętniczym losie. Jeszcze inaczej: gdy w wersji pierwszej (skreślonej) oraz w wersji ostatniej, Narcyz nie mógłby żyć nad Wisłą (bo nie ma tu dlań „warunków do życia”), w wersji „środkowej” to właśnie ludzie żyjący nad Wisłą okazują się swoiście narcystyczni, bezustannie wpatrzeni we własny wizerunek odbity w wodach przygnębiającej rzeki. Zarazem samoudręczeni i samoupojeni - swoim koszmarnym wizerunkiem.

W pochodzącym z lat pięćdziesiątych wierszu Wista mit narcystyczny staje się źródłem metafory dla dyskursu o narodowej historii, teraźniejszości i przyszłości; w kreślonym w latach osiemdziesiątych i dziewięćdziesiątych opowiadaniu Narcyz ten sam mit nie zostaje już w żaden, najdrobniejszy nawet sposób, odniesiony do „sprawy polskiej”. Są to więc niewątpliwie dwa odrębne, istotowo różne, wzajemnie izolowane - literackie użycia mitu. A jednak, zauważmy, łączy je zadziwiające podobieństwo. W obu wypadkach, pracując nad tekstem nawiązującym do mitu narcystycznego, Herbert ma zasadniczy problem z finalizacją pracy. Wiersz Wista nigdy nie został doprowadzony do postaci klarownego czystopisu, nigdy nie ukazał się 
drukiem. Ostatecznie ocalał zeń jedynie finałowy czterowiersz, który stał się puentą wiersza Prolog ogłoszonego w tomie Napis. Opowiadanie Narcyz powstawało z trudem, rozpadało się na przerywane i zarzucane warianty $i$, ostatecznie, Herbert nie zdołał podać go do druku. Narcyz, dziwnym trafem, wikłał się w projekty przysparzające poecie znacznych pisarskich trudności.

\section{Czy Herbert zabił muchę i Narcyza?}

W dossier małej prozy pt. Narcyz natrafiamy i na taki zapis:

Od wielu lat mit o Narcyzie niepokoji mnie,

od razu dodam żeby chwycić byka za rogi

ale niepokoi nie wsposób twórezy w sposób jałowy

przypra

przyprawiając

całkiem nietwórczy, przyprawiający o rosnącą iry

wiając

tację - jak wielka czarna mucha która wpadła

wczesnym popołudniem

do pokoju kiedy pewnego sierpniowego rozłożyłem się

na staroświeckim szezlągu z książką w ręku i

rozkoszną

błogą nadzieją w sercu że utnę sobie drzemkę a wtedy

gdy do pokoju wpadła wspomniana już okropna

mucha i od razu pomyślałem o Narcyzie (mucha

i Narcyz stanowity w moim umyśle nierozłączną parę

owego i właśnie wtedy 4 lipca roku 199. Postanowiłem skończyć

pamięt z tym wyrażając się naukowo - natręctwem myślowym

nego męskim

17. VII i jednym energicznym męskiem uderzenie zabić za jednym zamachem zabić muchę i Narcyza

(AZH, akc. 17 955, t. 155, s. 10)

W dalszym ciągu zapisu z Notatnika nr 155 Herbert formułuje jeszcze kilka stwierdzeń:

a) że nigdy nie mógł dostrzec głębszego sensu mitycznej opowieści („Narcyz wydawał mi się zawsze fatalnie nudny"),

b) że jedynym twórcą w historii literatury, który postać Narcyza zdołał ciekawie przedstawić był Owidiusz („ale on potrafił wszystko”),

c) że Narcyz stał się bohaterem psychoanalizy, jednakże ten rodzaj poznawczej aktywności człowieka budzi poważne wątpliwości co do swej prawomocności oraz użyteczności („warto zastanowić się nad skuteczną szczepionką przeciw psychoanalizie"). 
Pod ostatnim zdaniem tej wersji Herbert zapisał datę: 17 lipca 1996 roku.

Zdecydowaną większość analizowanych w tym artykule brulionowych ujęć postaci Narcyza już sporządzono w ów lipcowy dzień (czy raczej: w owe lipcowe dni), gdy powstawał zapis z Notatnika nr 155. Niewykluczone zresztą, że sporządzone były już wszystkie z nich, że to akurat podejście do narcyzowego tematu okazało się podejściem ostatnim. Na pewno zaś transliterowaną wyżej inskrypcję potraktować wolno jako komentarz do długiego okresu „narcystycznych wariacji”.

Rzeczywiście, mit Narcyza „niepokoił” wyobraźnię Herberta - przyglądaliśmy się już materialnym świadectwom owego niepokoju. Rzeczywiście też niepokoił - „od wielu lat”. Utworem pt. Narcyz Herbert zajmował się od końca lat siedemdziesiątych, a jeśli uwzględnić jeszcze wiersz Wista z lat pięćdziesiątych i pojawiający się w nim motyw polskiego Narcyza, otrzymamy obraz doprawdy „wieloletniej” obsesji tematycznej. I wreszcie: to wieloletnie niepokojenie istotnie przebiegało „w sposób jałowy i całkiem nietwórczy”, wszak niemal wszystkie próby zbudowania tekstu o Narcyzie szybko się urywały, zawieszały, zaś te nieliczne, które osiągnęly postać domkniętą, zostały utrwalone w formie maszynopisu bądź komputeropisu, nie były kierowane do druku przez autora.

Cytowany passus zawiera prywatną, autorską metaforę, opisującą przebieg procesu twórczego, procesu pisarskiego: to metafora przemocowa. Jej semantyka, warto zauważyć, nie jest w pełni jasna. Co bowiem oznacza tutaj figuratywne zabicie natrętnej muchy? Na pewno wyzwolenie się z obsesji rozmyślań nad mitem. Ale w jaki sposób? Czy poprzez napisanie - wreszcie - tego jednego jedynego, w pełni przekonującego utworu, zawierającego ostateczną, optymalną reinterpretację mitu? Czy raczej poprzez definitywne zaniechanie prób reinterpretacji, pogodzenie się z faktem, że tak długo obmyślany utwór ani nie został, ani też nie zostanie już nigdy - napisany? Trudno na to pytanie odpowiedzieć jednoznacznie, nie mamy przecież bezpośredniego dostępu do intentio auctoris. Nie możemy też orzec w sposób argumentatywny, czy Herbert w ogóle „zabił muchę”, to jest uwolnił się od obsesji reinterpretowania mitu, czy też - mimo zapowiedzi składanej w Notatniku nr 155 - za „muchą” uganiał się aż do końca swej pisarskiej aktywności (to znaczy: aż do śmierci „nie dał sobie spokoju” z Narcyzem). Wszystkie te pytania wiodą w ciemną, niemożliwą już do rozświetlenia, przestrzeń pisarskiej tajemnicy.

\section{Punkt dojścia: genetyczna edycja Narcyza}

Decyzja podjęta przez pierwszych edytorów - a więc wypreparowanie z Herbertowskich „wariacji narcystycznych” jednego tekstu, niekoniecznie naj- 
późniejszego, nie wiadomo czy najsilniej przez autora akceptowanego, na pewno jednak najbardziej przezeń dopracowanego - ma swoje oczywiste racje i uzasadnienia. Nie zgłaszam wobec niej żadnych zastrzeżeń. Chcę jedynie poddać pod rozwagę możliwość zbudowania edycji o innym charakterze, celu, zapewne również o innym (węższym) adresie użytkowników. A więc: edycji genetycznej.

Przedsmak edycji, o której tutaj myślę, daje rozwiązanie przyjęte przez Ryszarda Krynickiego, który - dokonując w roku 2001 próby pieczołowitej edytorskiej rekonstrukcji Króla mrówek, musiał też oczywiście zaproponować redakcję należącego do tejże całości Narcyza. Krynicki, po gruntownym zapoznaniu z materiałami archiwalnymi, zamieścił w „swoim” Królu mrówek tę wersję Narcyza, która doczekała się dwa lata wcześniej pierwodruku na łamach „Zeszytów Literackich”. „Rdzeń” książki uzupełnił jednak Aneksem, opatrzonym podtytułem Inne wersje niektórych utworów - tam również podał do druku nigdy dotąd niepublikowaną inną wersję Narcyza, zasadniczo różniącą się od postaci przyjętej za "podstawową" (pod względem leksyki, frazeologii, długości, sposobu ujęcia mitu), także jednak utrwaloną w postaci komputeropisowej i (względnie) dopracowaną.

Genetyczna edycja Narcyza byłaby działaniem bardziej radykalnym. Udostępniłaby mianowicie ( $\mathrm{w}$ formie transliteracji oraz barwnych reprodukcji) wszystkie zachowane świadectwa pracy Zbigniewa Herberta nad mitem Narcyza, wszystkie istniejące zapisy - także i te urwane, niedokończone, fragmentaryczne. Edycja taka byłaby niewątpliwie zbiorem wariantów, jednakże nie wariantów jednego utworu, lecz wariantów reinterpretacji jednego mitu, wariantów wyrażających się w wielu (przeważnie nieukończonych) utworach, mających jeden wspólny tytuł: Narcyz.

Edycja, o której tutaj myślę, miałaby do zaoferowania swemu użytkownikowi jedną możliwość: mianowicie możliwość obcowania z „brulionową polifonią" czy, jak kto woli, z pełnym spectrum „narcystycznych wariacji” Zbigniewa Herberta. A więc ze zjawiskiem, które w moim artykule poddane zostało opisowi. Dodajmy - opisowi z konieczności niepełnemu. Nie przytoczyłem tu przecież - za pomocą transliteracji - wszystkich istniejących prób („półprób”, „ćwierćprób”) zbudowania utworu reinterpretującego kanoniczną narrację mitologiczną, nie wydobyłem wszystkich odcieni i momentów Herbertowskiej subwersji. Mój krytyczno-genetyczny dyskurs miał charakter niewątpliwie selektywny. Genetyczna edycja Narcyza - czy raczej, jak wolę mówić, całej serii niedokończonych utworów pt. Narcyz, pisanych przez Zbigniewa Herberta w latach osiemdziesiątych i dziewięćdziesiątych ubiegłego wieku - pozwoliłaby czytelnikowi na dokonywanie własnych obserwacji (być może odmiennych niż przedstawione w niniejszym szkicu), na indywidualne rozkładanie akcentów (niewykluczone, że inne od mojego akcentowania), słowem: na bezpośrednie, a nie zapośredniczone w narracji badacza, doświadczanie przyjemności przedtekstu. 


\section{Bibliografia}

Adamiec M., „...Pomnik trochę niezupetny... ”. Rzecz o apokryfach i poezji Zbigniewa Herberta, Gdańsk 1996.

Antoniuk M., Stowo raz obudzone. Poezja Czestawa Miłosza. Próby czytania, Kraków 2015.

Archiwum Zbigniewa Herberta. Inwentarz, oprac. Henryk Citko, Warszawa 2008.

Grimal P., Stownik mitologii greckiej i rzymskiej, tłum. M. Bronarska i in., wyd. 2, Wrocław 1990.

Herbert Z., Listy do Muzy, Gdynia 2000.

Herbert Z., Narcyz, „Zeszyty Literackie” 1999, nr 68.

Herbert Z., Miłosz C., Korespondencja, Warszawa 2006.

Nycz R., W stronę humanistyki innowacyjnej. Tekst jako laboratorium, „Teksty Drugie" 2013, nr 1-2. 